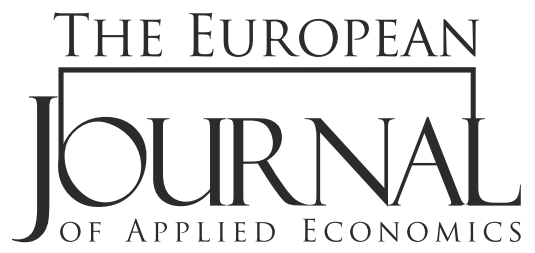

\title{
THE ROLE OF TECHNOLOGY AS AN ABSORPTIVE CAPACITY IN ECONOMIC GROWTH IN EMERGING ECONOMIES: A NEW APPROACH
}

\author{
Richard Angelous Kotey*, Joshua Yindenaba Abor \\ Department of Finance \\ University of Ghana Business School
}

\begin{abstract}
:
Studies have shown that the effects of Foreign Direct Investment (FDI) on economic growth have not always been direct, especially in developing regions; certain characteristics must exist in the economy for the effects of FDI to be well absorbed. Therefore, this study sought to assess the economic impact of FDI on economic growth in Sub-Saharan African (SSA) countries, factoring in technology as an absorptive capacity. Because of the scarcity of data on a viable proxy for technology in the African context, we measure technology in a novel approach, using annual number of published innovation-related papers as a proxy for technological presence. Data from forty-three Sub-Saharan countries over a 19-year period (from 1990 to 2008) was analyzed. Using a Fixed Effects (FE) regression model, the study found that FDI had a negative and significant effect on GDP, which is our proxy for economic growth. However, when FDI is interacted with technology, the relationship turns positive and significant. This implies that countries with technological presence are more able to absorb from FDI than those with little technology. Furthermore, the study found that countries with high technology were able to absorb more from FDI than those with low technology.
\end{abstract}

\section{Keywords:}

foreign direct investment, technology, innovation, absorptive capacity

Jel classification:

C23, O47, F23, O11 


\section{INTRODUCTION}

Foreign Direct Investment (FDI) has been an important mechanism for universal growth and development through trade and economic interaction since the emergence of globalization in the last three or so decades. This is especially so for developing countries because of their peculiar challenges, the difficulty in assessing the international capital market, weak domestic markets, and low levels of income and savings. Therefore, developing nations tend to look beyond their borders for investment that will generate enough growth for them. FDI and official loans from multinational institutions (such as the IMF and World Bank) have been viable means of accessing such capital investments (Aseidu, 2002). In the case of FDIs, the main drivers at the national level -that is, the policymakers- have implemented reforms to promote trade among countries which foster economic advancement. This has led to the progressive breakdown of international barriers (Twarowska \& Kakol, 2013), and improved shared prosperity among countries with competitive advantage and efficiency. Not only has this made investment opportunities available for both the private and public sector (Sinani \& Meyer, 2004), but also a means through which technology innovations can be shared (IMF, 1991; Meyer, 2001).

Multinational Corporations (MNCs) play a major role in global innovation (Kotey, 2019). According to a UNCTAD report in 2005, one half of the world's total expenditure in R\&D comes from MNCs. This figure increases to more than two-thirds when considering the cost of R\&D in the business sector alone (UNCTAD, 2005). It is, therefore, no surprise that about 80 percent of the world's technologies are owned by MNCs (Dunning, 1992). Much of the research MNCs undertake is usually done in developed economies; little or no research is done in developing economies (UNCTAD, 2005; UNCTAD, 2010; Kotey, 2019). This may account for the widening technology gap between the developing and developed economies. However, through interaction between MNCs and local firms in developing economies, particularly through direct investments, knowledge and technology may trickle down to the local firms, particularly through mechanisms like imitation, competition, and backward and forward linkages.

Table 1 R\&D Expenditure of Selected MNCs and Other Countries

\begin{tabular}{|c|c|c|c|c|}
\hline MNC & $\mathrm{R} \& \mathrm{D}$ & $\begin{array}{l}\text { Expenditure (in } \\
\text { million } \$ \text { ) }\end{array}$ & Countries & $\begin{array}{c}\text { R\&D Expenditure in } \\
2009 \text { (in million } \$ \text { ) }\end{array}$ \\
\hline Toyota & & 9403 & USA *(2013) & 473400 \\
\hline Microsoft & & 8437 & China $^{\star}(2015)$ & 409000 \\
\hline VW & & 8043 & Germany & 11799.80 \\
\hline Pfizer & & 7507 & United Kingdom & 8731.63 \\
\hline Novartis & & 7163 & Japan & 4185.27 \\
\hline Nokia & & 6942 & Canada & 3639.43 \\
\hline Johnson \& Johnson & & 6764 & Sweden & 3251.97 \\
\hline Samsung Electronics & & 6265 & Brazil & 343.55 \\
\hline General Motors & & 5875 & Ethiopia & 5.48 \\
\hline Honda Motors & & 5857 & South Africa ${ }^{\star}(2012)$ & 4.80 \\
\hline Daimler & & 5785 & Botswana & 1.95 \\
\hline Intel & & 5473 & Rwanda & 0.24 \\
\hline Sony & & 5172 & Côte d'Ivoire * (2010) & 0.14 \\
\hline IBM & & 4787 & Benin & 0.04 \\
\hline Takeda Pharmaceutical & & 4712 & Togo & 0.02 \\
\hline
\end{tabular}

Author's own computation. R\&D expenditure of selected MNCs and countries in 2009. Source UNCTAD 2010 
Technology is an important tool for firms to remain competitive both on the micro and macro levels. Technology improves the quality of outputs, reduces the production and processing time, and reduces the cost of production (UNCTAD, 2010). It is key for a country to have relevant and contemporary technology. However, because of the cost of creating modern technology, developing economies tend to be handicapped in this aspect, as they mostly cannot afford it. Still, through trade globalization, technology can be transferred through contagion. This occurs through the rub-off effect as companies interact in the global market. Through this effect, knowledge is able to trickle down from the developed economies, which usually have more technology, to developing economies, which usually have less technology.

The economic impact of FDI on growth has been well researched in academia (Alfaro, Chanda, Kalemli-Ozcan \& Sayek, 2004; Borensztein, De Gregorio \& Lee, 1998; Carkovic \& Levine, 2005; Chakraborty \& Nunnenkamp, 2008; Li \& Liu, 2005, Kotey 2019; Kombui \& Kotey, 2019). Though some studies have been done on technology as a spillover effect on FDI (Blomstrom \& Kokko, 1996; Bwalya, 2006; Dutse, 2012; Ghali \& Rezgui, 2008; Marin \& Bell, 2006; Sinani \& Meyer, 2004), few studies have adopted technology as an absorptive capacity ${ }^{1}$ in an FDI-economic growth relationship (See Figure 1). A typical study that has looked into absorptive capacity is Agbloyor, Gyeke-Dako, Kuipo, \& Abor (2016), who looked at the relationship between FDI and growth when institutions are factored in, and found that countries with strong institutions have higher economic growth through FDI than countries with weak institutions. Although studies on technology have shown that FDI is a major way technology reaches developing economies, not many studies have looked at its effect as an absorptive capacity on economic growth (Liu, 2008; UNCTAD, 2010). There is, therefore, a need for a critical look at FDI on economic growth from the lens of technology as an absorptive capacity. Also, there is still very little evidence on the impact of technology as an absorptive capacity on economic growth factoring in FDI in an African context (Figure 2). The reason is partly due to little data being available on technology; there are very few variables to measure technology in African countries, mainly because most of the countries do not have data on $R \& D$, patents, etc. This paper is unique in that it examines the impact of FDI on growth in Sub-Saharan African (SSA) countries using technology as an absorptive capacity. It also adopts a new approach to measure technology by using the presence of published technologyenhancing research in the host country as a proxy for technological presence.

Figure 1 Published Articles over Selected Time Frame

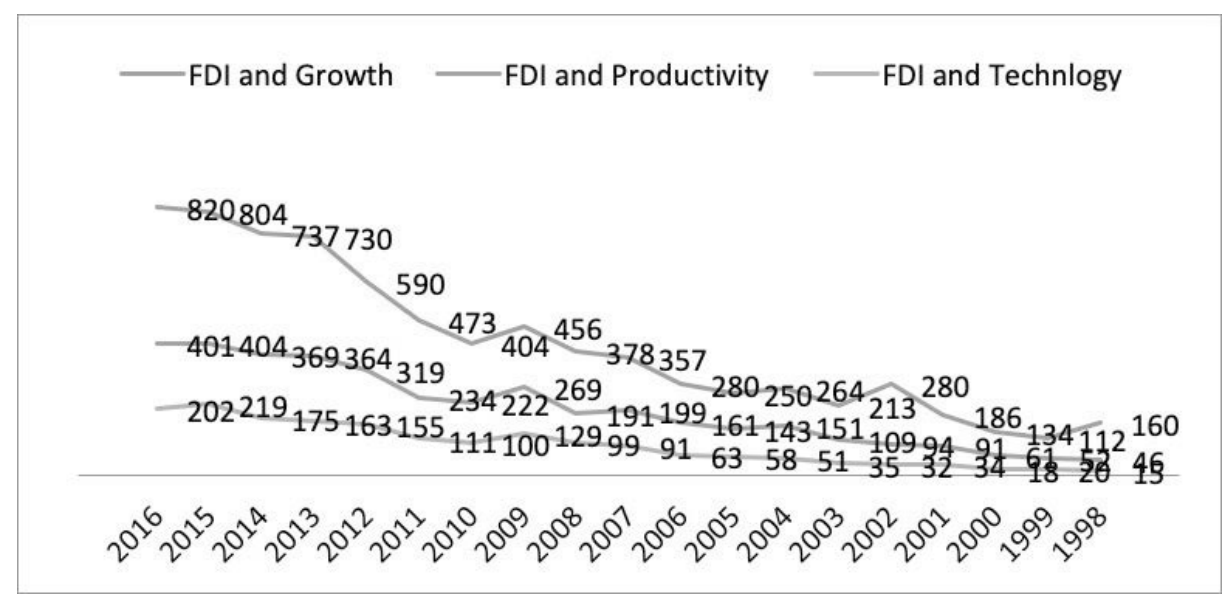

Author's own computation. The authors counted all published articles on FDI effects on growth and productivity, as well as FDI on technology from 1998 to 2016 within the science direct database. The graph shows that there have been few studies on FDI and Technology over the years among the three categories.

1 Absorptive capacity, as defined by (Rehman, 2016), is the capability of host economies to absorb or internalize external traits from FDI spillovers. That said, if a host form has a high absorptive capacity, it would be able to benefit or absorb more from FDI, and vice versa. 


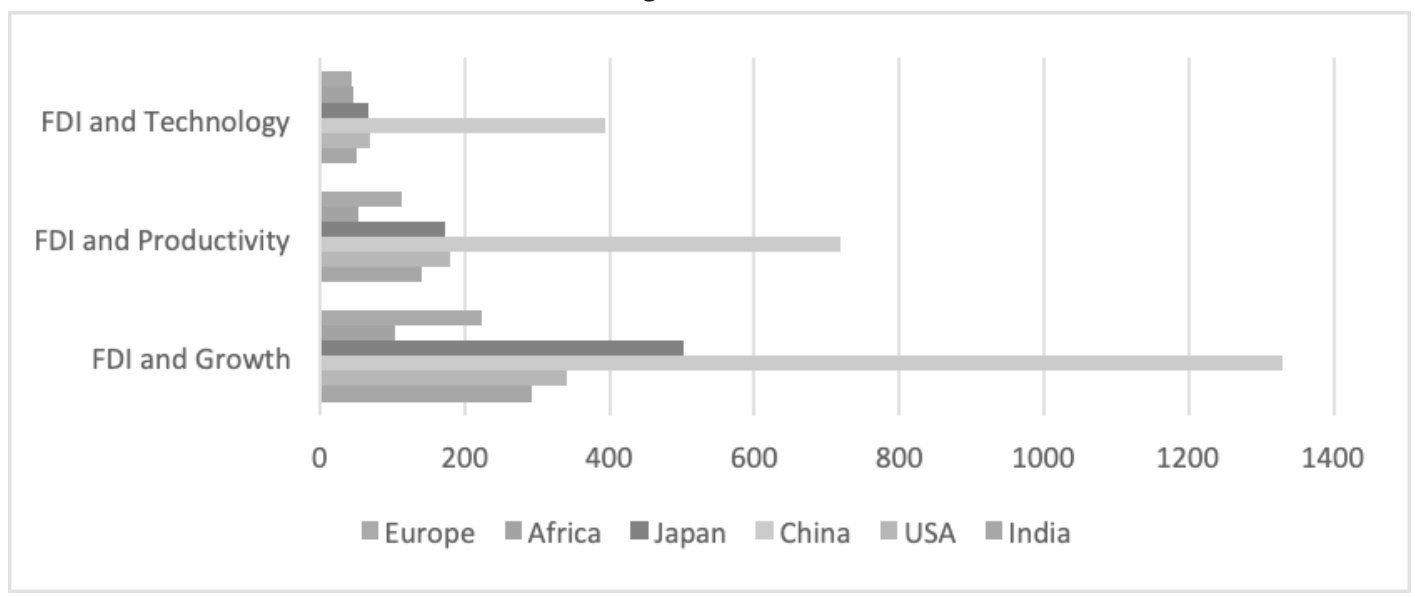

Author's own computation. Data from Science direct.

\section{LITERATURE REVIEW}

Studies on FDI and economic growth broadly fall into two categories; studies that have found a direct relationship between FDI and economic growth, and studies that have found that the relationship between FDI and growth is not so direct, thus absorptive capacities form part of the relationship. For example, in some developing economies, it was more challenging for researchers to find a consistent relationship between FDI and economic growth. Instead, they tested the relationship on the presence of absorptive capacities (Clark, Highfill, Campino, \& Rehman, 2011; Kotey, 2019).

Some studies that found FDI's effect strengthened with the presence of an absorptive capacity include Agbloyor, Gyeke-Dako, Kuipo, \& Abor (2016); Borensztein, De Gregorio, \& Lee (1998); Li \& Liu (2005); Ramirez (2006); Rehman (2016); Sinani \& Meyer (2004). Li and Liu (2005) researched 84 countries (from developed and developing economies) from 1970 to 1999, examining the causal relationship between FDI and economic growth. They found that the relationship between economic growth and FDI is strong and positive when interacted with human capital. Borensztein et al. (1998) also found a similar result; human capital positively affects FDI and growth. Other studies have shown a link between FDI and technology. Ramirez (2006) conducted a study in Mexico using a 1960 to 2001 time-series data. He found out that FDI increased labour productivity. Additionally, Sinani and Mayor (2004) studied the spillover effect from technology from FDI, sampling domestic firms in Estonia from the period from 1994 to 1999 . Their study revealed that the magnitude of technology spillover depended on the characteristics of both the FDI inflow and the local firm; the magnitude of foreign presence and the firm size affected the spillover effect. Chakraborty and Nunnenkamp (2008) also did a similar study in India. They found that trade liberalization magnified FDI's effect on domestic companies. 


\section{Theoretical Framework on technology as an absorptive capacity}

There are theories that have been used to explain FDI, such as the product life cycle theory, exchange rate theory, dunning's eclectic paradigm, among others. But these theories explain only FDI. In order to find a meaningful theory to explain technology as an absorptive capacity to FDI, we delve into theories in the area of industrialization. Specifically, the main theories that underpin the study are the dependency and modernization theory.

\section{Dependency Theory}

Dependency theory first emerged in the early 1970s. Dependency theory thrives on the following assumptions: that the world is a capitalist economy, that foreign investments always move from developed economies to developing ones, and that developed nations extract resources from developing nations (Apter, 1987; Larrain, 2013; Scott, 1995; So, 1990). Dependency theorists believe that FDI does not lead to economic growth, at least not in the long run. They believe that, through foreign investment, developed countries deprive developing countries of the natural resources they need to develop, making them dependent on the foreign firms or states for economic growth. Thus, they become monopolists, causing unfair completion in the local markets (Adams, 2009). Sylwester (2005) also stated that dependency theorists believe FDI has a crowding-out effect that affects domestic investment by raising the costs of investments and also causing market distortions that are detrimental to economic growth and development. We assume that foreign investors coming into SSA countries out-compete the local firms due to their better innovations (Matunhu, 2011), thereby creating an opportunity technology to be shared or transferred.

\section{Modernization Theory}

Modernization theory first appeared in the 1950s and 1960s, and has evolved over time (up to the late 1990s). It has no single proponent, but has been attributed to American social scientists from the early 1950s (Preston, 2012). As it evolved, its definition has expanded (Fourie, 2012; Lehmann, 2010). The modernization theory generally explains how a country modernizes or changes from its traditional way of life to a modern one (Apter, 1987; Scott, 1995; So, 1990). The study adopts the Economic version of the Modernization Theory. This theory explains how technology and social innovations are able to spur growth. The study is particularly supported by the Diffusion of Innovations Theory, which essentially explains why innovation spreads, and measures the rate at which it is able to spread. On the other hand, the Economic Modernization Theory specifically stipulates that FDI is necessary for economic progress in a country. This study agrees with the modernization theory, in that developing economies cannot obtain the technology needed for economic growth without the presence of FDI. FDI provides the necessary resources the local economies require to swiftly achieve economic development. The model for the study also supports this thinking.

Based on these underlying frameworks, we hypothesize that the presence of technology affects the ability of a country to absorb more of the effects of FDI. 


\section{METHODOLOGY}

A quantitative research approach was adopted for the study. An unbalanced annual panel data of 43 Sub-Saharan African countries from 1990 to 2008 was used for the study. We employed a fixed effects (FE) model estimation after conducting preliminary tests; we conducted a Hausman test to determine the model appropriateness, and tested for heteroscedasticity, endogeneity, simultaneity, and reverse causality issues (see Appendix 3). The large number of countries and multiple years give a higher degree for freedom and credibility to the findings of the study (Brooks, 2008; Baltagi, 2001; Jensen 2012).

For reciprocity, the data (DOI:10.17632/tfjwys9s5p.1) used for the study has been uploaded on the Mendeley data repository, which can be retrieved from https://data.mendeley.com/datasets/tfjwys9s5p/1. The main statistical software used to analyze the data is STATA.

\section{Regression Model}

The regression model takes the form;+

$$
y_{i t}=\alpha+\beta \chi_{i t}+\mu_{i}+\varepsilon_{i t}
$$

Where $\boldsymbol{Y}$ is the dependent variable for country $\boldsymbol{i}$ at time $\boldsymbol{t}$ and $\boldsymbol{X}$ is a set of explanatory variables for country $\boldsymbol{i}$ at time $\boldsymbol{t} . \boldsymbol{\mu}_{\boldsymbol{i}}$ is the country-specific fixed effect, which is timeinvariant. $\boldsymbol{a}$ is the constant term. $\boldsymbol{\beta}$ represents the coefficients to be estimated for the independent variables, and $\varepsilon_{i t}$ is the error term or idiosyncratic noise.

The model for the study is specified as:

$$
G D P_{i t}=\alpha+\beta_{1} F D I_{i t}+\beta_{2} T E C H_{i t}+\beta_{3}(F D I * T E C H)_{\mathrm{it}}+\sum_{j}^{\mu i}={ }_{1} \beta_{j} X_{i t}+\mu_{i}+\varepsilon_{i t}
$$

Here are the interpretations:

$a$ denotes the constant. It is the expected value of the dependent variable when all independent variables are set to zero.

FDI $\boldsymbol{I}_{i t}$ denotes the Foreign Direct Investment (FDI) net inflows into country $\boldsymbol{i}$ at time $\boldsymbol{t}$. It refers to direct investment equity flows entering into a country. It can also be said to be the net inflows from foreign investment enough to acquire at least 10 percent voting rights in a domestic firm. It is the sum total of equity capital, reinvestment of earnings, and other capital.

$\beta_{1}$ is the coefficient of FDI to be estimated in the regression model. We expect a relationship other than positive because of our sample set. Studies done in developing economies usually show a negative relationship.

$\mathbf{T E C H}_{u}$ denotes the Technology variable for each country and each year. We proxy technology by the number of annual publications in scientific and technical journal articles, which is an indication of the presence of innovation or technology in the local country. This refers to the sum of scientific and 
engineering articles or publications in physics, biology, chemistry, mathematics, clinical medicine, biomedical research, engineering and technology, and earth and space sciences fields published within the year. We assume that this type of technology or innovation is growth-enhancing. We also impose an assumption that technological presence is reflected in the number of local applied science papers published.

$\beta_{2}$ denotes the coefficient for $\mathbf{T E C H}$ variable. We expect a positive relationship indicating the positive relationship between economic growth and technology.

$\left(\boldsymbol{T E C H}^{\star} \boldsymbol{F D I}\right)$ denotes the interaction between $\boldsymbol{F D I}$ inflows and Technology. We refer subsequently to this variable as our interaction term.

$\beta_{3}$ represents the coefficient of the interaction term. We expect the interaction to be positive. A positive coefficient suggests that countries with the presence of innovation or technology are better able to absorb FDI. Thus, the countries are able to benefit from FDI in terms of achieving higher levels of economic growth.

$X_{i t}$ denotes the control variables. We include a set of information conditions to be sure we are capturing the effect of technology and FDI indicators on economic growth. Following Adams (2009) and Agbloyor et al. (2016), our control variables include; government expenditure, political stability, labour force, and trade openness.

Table 2 Model Variables, Interpretation and Sources

\begin{tabular}{|c|c|c|}
\hline Variable & Meaning and interpretation & Source \\
\hline $\operatorname{lnFDI}$ & $\begin{array}{l}\text { Annual FDI inflows coming into the country. The vari- } \\
\text { able is log-transformed to reduce variation and make it } \\
\text { normally distributed. }\end{array}$ & $\begin{array}{l}\text { International Monetary } \\
\text { Fund(IMF), Balance of Payments } \\
\text { database }\end{array}$ \\
\hline Tech & $\begin{array}{l}\text { Technology present in the host country. Measured by } \\
\text { the number of annual publications in applied science } \\
\text { journals. }\end{array}$ & $\begin{array}{l}\text { National Science Foundation, Sci- } \\
\text { ence and Engineering Indicators. }\end{array}$ \\
\hline lninteraction & $\begin{array}{l}\text { Absorptive capacity: derived by } \mathrm{FDI}^{\star} \mathrm{TECH} \text {. The vari- } \\
\text { able is log-transformed to reduce variation and make it } \\
\text { normally distributed. }\end{array}$ & World Bank data \\
\hline $\ln G D P$ & $\begin{array}{l}\text { Annual GDP in constant US\$. The variable is log- } \\
\text { transformed to reduce variation and make it normally } \\
\text { distributed. }\end{array}$ & $\begin{array}{l}\text { World Bank national accounts, } \\
\text { OECD national accounts }\end{array}$ \\
\hline $\ln \mathrm{Expcu}$ & $\begin{array}{l}\text { Annual government expenditure in constant US\$. The } \\
\text { variable is log-transformed to reduce variation and } \\
\text { make it normally distributed. }\end{array}$ & World Bank national accounts \\
\hline Pstab & $\begin{array}{l}\text { Political stability. Measures the level of political free- } \\
\text { dom (legal and political risk) in the country. }\end{array}$ & World Governance Indicators \\
\hline Open & $\begin{array}{l}\text { Country openness to the external world. Measured by } \\
\text { the sum of imports and exports multiplied by GDP }\end{array}$ & $\begin{array}{l}\text { World Bank national accounts } \\
\text { data, OECD national accounts } \\
\text { data }\end{array}$ \\
\hline Labper & $\begin{array}{l}\text { Labour force. Defined as people } 15 \text { years and older who } \\
\text { meet the International Labour Organization definition } \\
\text { of the economically active population. }\end{array}$ & $\begin{array}{l}\text { International Labour Organization } \\
\text { database }\end{array}$ \\
\hline
\end{tabular}




\section{Justification of Technology Variable}

The common proxy for measuring technology (see Appendix 1) in literature has been intellectual property rights (patents, copyrights, industrial design, and utility model, etc.), and R\&D factors, such as R\&D expenditure, employees, etc. (see Branstetter, Fisman , \& Foley, 2006; João , 2010; Liu, 2008; Neven \& Siotis, 1996). Considering such data is non-existent for Sub-Saharan Africa, this study uses a new approach for measuring technology from FDI.

We use the annual sum of scientific and technical journal publications by each country as a proxy. In our estimation, journal publications represent new knowledge or technology that has been found or created. We expect a positive relationship with economic growth (see Appendix 2).

To use this variable as a proxy for technology, we make some key assumptions;

1. Applied science publications in the respective countries represent technology creation or technological presence.

2. This type of technology is economic growth-enhancing.

3. The relationship between technology and the number of applied science publications is positive.

\section{Descriptive Statistics}

The table below presents the descriptive statistics:

Table 3 Descriptive Statistics

\begin{tabular}{lccccc}
\hline Variable & Observations & Mean & Std. Dev. & Min & Max \\
\hline lnGDP & & & & & \\
InFDI & 808 & 9.521283 & 0.581875 & 8.003491 & 11.47627 \\
Tech & 803 & 7.608242 & 1.006778 & 2 & 9.994977 \\
\hline lninteraction & 785 & 156.7213 & 598.5485 & 0.2 & 6137.3 \\
lnExpcu & 776 & 8.962239 & 1.533451 & 2.897627 & 13.78295 \\
\hline Open & 728 & 8.679416 & 0.594942 & 7.176319 & 10.7284 \\
\hline Labper & 778 & 73.12675 & 49.07174 & 0 & \\
Pstab & 789 & 0.108678 & 0.083699 & 0.001791 & 0.419002 \\
\hline
\end{tabular}

Because the SSA countries in the model are from both developed, under-developed and developing economies, there is a wide variation in their GDP values.

Observing the log-transformed values of FDI and GDP, GDP has a higher mean than FDI, as expected. But, the FDI variable shows a higher variation than that of GDP, which shows that FDI inflows in the dataset vary much widely as compared to the GDP values. 
The mean value of the technology variable of 156.72 indicates that, on average, 157 publications are published annually by the SSA countries in our dataset, and this varies by about 599 publications. The mean of the log-transformed government expenditure is similar to the mean of the interaction term, but its standard deviation is lower, indicating a lower variation.

Trade openness accounts for how open the SSA countries are to the external world. On average, the level of trade openness is $7313 \%$, with a standard deviation of $4910 \%$.

On average, about $11 \%$ of the population is over 15 years and economically active in the sampled data. The standard deviation of $8 \%$, which shows how little variation is within the mean.

The political stability data only starts from 1996, hence the lower number of observations of 430 . On average, the level of political stability is -0.48 , which is not surprising, generally, because the level of political stability is very low among SSA countries.

\section{Correlation and Covariance}

The strength and direction of correlation among the individual variables are demonstrated in the correlation table.

Table 4 Correlation Table

\begin{tabular}{|c|c|c|c|c|c|c|c|c|}
\hline & $\operatorname{lnGDP}$ & $\operatorname{lnFDI}$ & Tech & lninteraction & $\ln \operatorname{Exp}$ & Open & labper & pstab \\
\hline $\operatorname{lnGDP}$ & 1.0000 & & & & & & & \\
\hline $\operatorname{lnFDI}$ & 0.6971 & 1.0000 & & & & & & \\
\hline Tech & 0.5976 & 0.3340 & 1.0000 & & & & & \\
\hline $\begin{array}{l}\text { Ininterac- } \\
\text { tion }\end{array}$ & 0.8438 & 0.8861 & 0.5162 & 1.0000 & & & & \\
\hline $\operatorname{lnExpcu}$ & 0.9457 & 0.6386 & 0.5983 & 0.8048 & 1.0000 & & & \\
\hline Open & -0.0468 & 0.2823 & -0.0779 & 0.0731 & -0.0283 & 1.0000 & & \\
\hline Labper & -0.4219 & -0.4879 & -0.2352 & -0.4604 & -0.4248 & -0.3828 & 1.0000 & \\
\hline Pstab & -0.0245 & 0.0750 & -0.0035 & 0.1114 & 0.0652 & 0.1746 & -0.4419 & 1.0000 \\
\hline
\end{tabular}

As can be seen from the table above, there is a stronger correlation between FDI and GDP, Tech and GDP, GDP and government expenditure, and the interaction term and GDP than expected, with correlations coefficients above 0.50 in all cases. The rest of the variables have a weak correlation with the dependent variable. FDI and the interaction term are strongly correlated, with a correlation coefficient of 0.89 , and this is expected, since the interaction term is the product of FDI and technology. The interaction term is also strongly correlated with Technology, with a coefficient of 0.512 . Moreover, government expenditure seems to be strongly correlated with GDP and the interaction term. The rest of the correlation coefficients are lower than 0.50 . 


\section{RESEARCH FINDINGS}

\section{Scatterplot matrix}

We present a scatterplot matrix to examine the pictorial relationship between GDP (in logged values), technology, the interaction term, and their log-transformed values.

In the scatterplot of the dependent variable and the interaction term, we observe a positive relationship. Further examinations show that the interaction term is high when GDP is high enough or reaches a certain point (or threshold). In the region where GDP is much lower (from 0 to 10), the interaction term remains leveled and close to zero. This may mean that, at low GDP levels, the technology is very low, and its absorptive capacity tends to be low also. But when GDP is high enough, the technology is high enough to absorb more from FDI.

We observe a positive relationship between the dependent variable and the log of the interaction term. However, there are no data points from point 0 to 5 on the logged interaction's axis. Above point 5 , we see the great number of data points clustered and from point 12 to 15 , we see much less clustering and data points. This may suggest there are more countries with low technology compared to those with high technology. That may also mean countries with low GDP's may have low FDI absorption compared with countries with high GDP's.

The relationship between technology and the interaction term is generally a positive one, albeit some data points show that high technology occurs even at low levels of technology. We thus see a bidirectional relationship in the scatterplot; one set shows that technology or technological presence is increasing when the level of the interaction term is also increasing; the other shows that technology is not much affected by the interaction term (indicating they are not affected by technology). The increasing positive relationship shows a positive relationship between technology and FDI.

\section{Figure 3 Scatterplot Matrix}

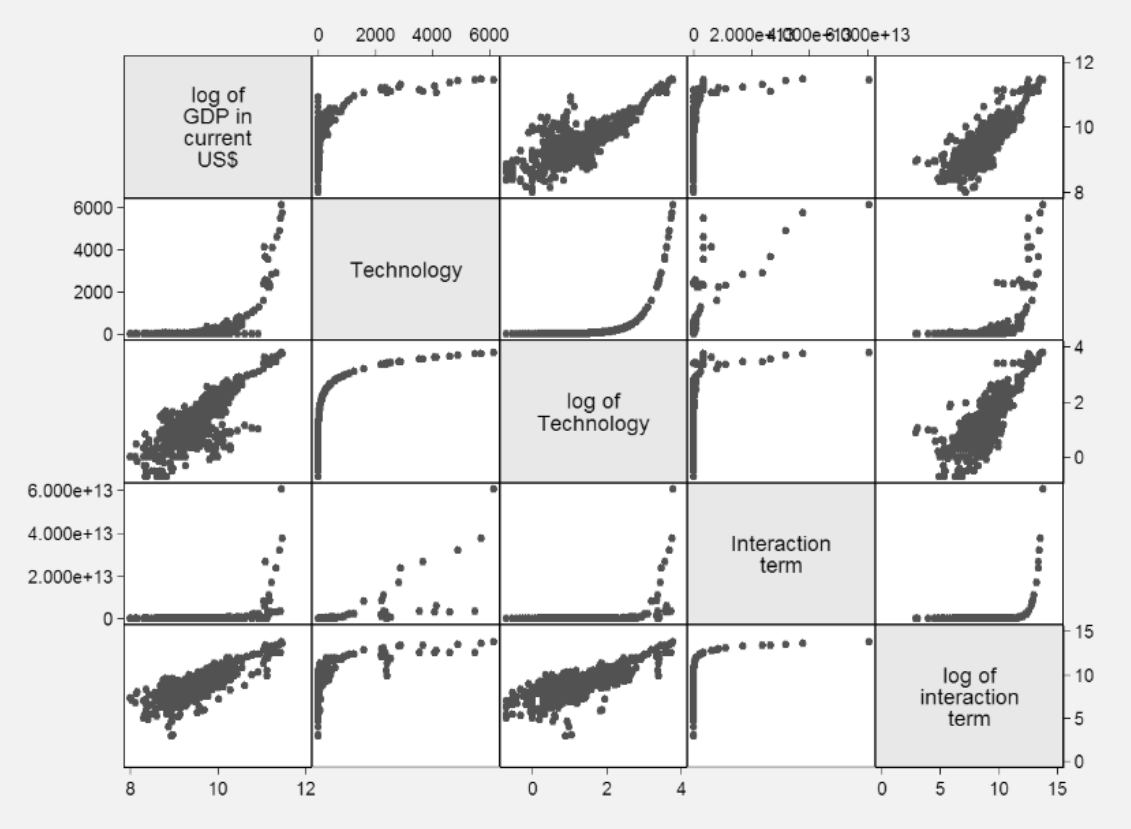

Source: Authors' own computation 
When we look at the relationship between the logged values of the technology and interaction term, we observe a similar positive relationship between them where the data points begin at some point and are clustered in the region closer to the origin.

\section{Regression analysis}

We estimate our regression model using fixed effects. We regress GDP on FDI, Technology, the interaction term, and the control variables. We also include an OLS regression as our first model for the sake of comparison. We present our fixed effects (FE) regression results in the second column labeled M2 (meaning model 2), and another FE regression result in model 3 (M3). In M1, we include all the variables in the regression and run an OLS regression. In M2, we include all our variables and run an FE regression. In M3, we remove political stability and run an FE regression. We include M3 because the number of observations reduces to about half when political stability is included in the model (because the data starts from 1996), so we remove it to observe whether a change in the sample observation could affect the results.

When we run on OLS, the technology variable is significant, at $10 \%$, and the interaction term is significant, at $1 \%$. The R-squared of $93 \%$ also suggests a high predictive power of the model. The coefficient of technology and its standard errors are positive, and close to zero. However, the coefficient for the interaction term is 0.07 , and significant at $5 \%$, showing that GDP increases by $0.07 \%$ when the interaction term is $1 \%$. As explained, the number of observations is 350 . As can be observed, the coefficient for the interaction term is higher than that of FDI. This may support the assertion that technological presence may have an increased effect of FDI on economic growth. We then proceed to our main regression results (M2 and M3) to see if the situation is the same or not.

$\mathrm{R}$-squared for the M2 is $88 \%$, signaling that $88 \%$ of the variation in GDP is caused by the independent variables in our linear model. The adjusted $\mathrm{R}$ square is $87 \%$, which is also high. Although this is a crosscountry study, it is not surprising to have such high R squares; as some studies on economic growth and FDI in Sub-Saharan Africa have had similar high R squares (Adams, 2009; Abor, 2010). The number of observation is 350 , and the number of groups is 38 . The table below presents the results of the regression.

Our independent variables are significant in M2 and M3 (at 1\% and 5\% significance levels), with the exception of political stability, which is insignificant. 
Table 5 Regression table (Fixed effects)

\begin{tabular}{|c|c|c|c|}
\hline & (M1) & (M2) & (M3) \\
\hline VARIABLES & $\operatorname{lnGDP}$ & $\operatorname{lnGDP}$ & $\operatorname{lnGDP}$ \\
\hline \multirow[t]{2}{*}{$\operatorname{lnFDIcu}$} & 0.0315 & $-0.104^{* * *}$ & $-0.0938^{* * *}$ \\
\hline & $(0.0223)$ & $(0.0203)$ & $(0.0154)$ \\
\hline \multirow[t]{2}{*}{ Tech } & $2.43 e-05^{\star}$ & $5.28 \mathrm{e}-05^{* * *}$ & $3.41 \mathrm{e}-05^{\star *}$ \\
\hline & $(1.37 e-05)$ & $(1.51 \mathrm{e}-05)$ & $(1.37 \mathrm{e}-05)$ \\
\hline \multirow[t]{2}{*}{ Ininteraction } & $0.0708^{\star \star \star}$ & $0.138^{\star * \star}$ & $0.117^{\star * \star}$ \\
\hline & $(0.0168)$ & $(0.0184)$ & $(0.0134)$ \\
\hline \multirow[t]{2}{*}{$\operatorname{lnExpcu}$} & $0.692^{* * *}$ & $0.384^{\star * *}$ & $0.521^{\star * *}$ \\
\hline & $(0.0254)$ & $(0.0303)$ & $(0.0249)$ \\
\hline \multirow[t]{2}{*}{ Open } & $-0.000717^{\star * *}$ & $-0.00212^{\star * \star}$ & $-0.00104^{* * *}$ \\
\hline & $(0.000205)$ & $(0.000151)$ & $(0.000147)$ \\
\hline \multirow[t]{2}{*}{ labper } & $-0.583^{* * *}$ & $-2.081^{* * *}$ & $-1.733^{* * *}$ \\
\hline & $(0.157)$ & $(0.184)$ & $(0.132)$ \\
\hline \multirow[t]{2}{*}{ pstab } & $-0.0778^{\star * *}$ & 0.00116 & \\
\hline & $(0.0107)$ & $(0.0108)$ & \\
\hline \multirow[t]{2}{*}{ Constant } & $2.737^{\star * *}$ & $6.162^{\star * *}$ & $4.954^{\star * \star}$ \\
\hline & $(0.197)$ & $(0.267)$ & $(0.220)$ \\
\hline Observations & 372 & 372 & 677 \\
\hline R-squared & 0.928 & 0.884 & 0.842 \\
\hline Adjusted R-squared & 0.9271 & 0.868 & 0.831 \\
\hline Number of countries & & 39 & 39 \\
\hline
\end{tabular}

Standard errors in parentheses $* * * p<0.01, * * p<0.05, * p<0.1$

In M2, we observe that lnFDI is significant, at a $1 \%$ alpha level, but has a negative effect on GDP, with a coefficient of 0.104 . This implies that GDP reduces by $0.104 \%$ when FDI inflows are increased by $1 \%$. In M3, the coefficient of FDI is much smaller, with a negative coefficient of 0.094 , signaling that GDP reduces by $0.094 \%$ when FDI is increased by $1 \%$. This is congruent with studies done on economic growth in Africa; FDI tends to be negatively related to GDP. Asiedu (2002) explained that FDIs that come to Africa are extractive in nature, and usually do not seek to satisfy or serve the local market. Therefore, they do not contribute as much towards economic growth as expected, aside from the taxes they pay to the local government and the low-level professionals they employ locally.

The technology variable is significant, at $99 \%$ and $95 \%$ confidence interval in M2 and M3, respectively. However, the coefficients are positive, and close to 0 . This means the technology present in the sample countries has a positive relationship with economic growth; however, its effect on economic growth is very minimal. This is in congruence with the observations from the scatter plot matrix.

When we interact FDI with technology, its effect is more pronounced on the dependent variable. We observe from the coefficients in M2 and M3, respectively, that GDP increases by $0.138 \%$ and $0.117 \%$ when the interaction term increases by $1 \%$, all being significant at a $1 \%$ level of significance. The coefficients show that FDI is more absorbed when technology is present in the host country, as observed by com- 
paring the coefficients of FDI and the interaction term. This may also mean that countries with higher technology are able to transform the negative impact of FDI on economic growth into a positive one.

Government expenditure also has a positive relationship on economic growth, and is very significant, at a $1 \%$ level of significance. The coefficients show that GDP increases by $0.384 \%$ and $0.521 \%$ in M2 and M3, respectively, when government expenditure increases by $1 \%$. This shows that, for SSA countries, government spending leads to higher economic growths, as government expenditures are generally aimed towards infrastructural and economy-wide growth.

Trade openness is also significant at a $99 \%$ confidence interval, although the effect to GDP is negative. The coefficients show that GDP reduces by $0.2 \%$, and $0.1 \% \mathrm{M} 2$ and M3 respectively, when trade openness increases by $1 \%$. We observed from our sample countries that imports generally exceed export levels, whilst exports are usually unprocessed raw materials and imports finished value-added products. This means trade openness harms, rather than benefits, economic growth.

This is also supported by the stylized fact that FDI that comes into SSA countries are usually in the extractive industry. Because a higher chunk of the FDI inflows coming into SSA countries goes into the extractive sectors (e.g. mining, oil exploration, etc.), the expected growth effect from these investments are not substantially beneficial to the local markets, since a higher portion of revenues are hauled into external markets.

Labour force is also significant, at a $1 \%$ level in all three models. However, the coefficients are negative in each case. The interpretation is that, although the sample countries do have a high labour force, this does not automatically translate into high economic growth. The authors reason that a high quantum of the labour force is mostly unskilled and unspecialized; therefore, they are not able to significantly increase output.

As expected, the political stability variable is positively correlated with GDP. However, the coefficient is insignificant, at a $5 \%$ alpha level.

\section{CONCLUSION}

There is evidence that technology increases, not only productively, but has a ripple effect on the economic growth of SSA countries. Technology mostly comes into developing economies through MNC engagements in the form of FDI. Since the level of technology present in the country also affects the country's ability to absorb FDI, SSA countries are not benefiting much from FDI due to low levels of the technology present in such economies. Hence, it is important for SSA countries to adopt technology-enhancing strategies in order to absorb more from FDI inflows.

\section{RECOMMENDATIONS}

Technology has a positive relationship with growth. Therefore, for an increase in economic growth, higher levels of technology are needed to absorb more from FDI inflows. Therefore, local governments in SSA countries must put measures into place that create and absorb higher levels of technology. Industrialization must be encouraged, businesses must be given the necessary impetus, and there should be an investment in young entrepreneurs. This will help increase the level of technology, and that will have a ripple effect on growth. 
In addition, not all FDI is beneficial to host countries' growth. This is why local governments must collaborate with MNCs that can help the economy. The extractive kind of FDI must be minimized.

Finally, local firms must be encouraged to collaborate with MNCs. Through collaborations, MNCs transfer - directly or indirectly- knowledge and technology to local firms. This could increase technological presence in the country.

\section{REFERENCES}

Adams, S. (2009). Foreign Direct Investment, domestic investment, and economic growth in Sub Saharan Africa. Journal of Policy Modeling, 31, 939-949.

Agbloyor, E. K., Gyeke-Dako, A., Kuipo, R., \& Abor, J. (2016). Foreign Direct Investment and Economic Growth in SSA: The Role of Institutions. Thunderbird International Business Review, 58, 479-497.

Alfaro, L., Chanda, A., Kalemli-Ozcan, S., \& Sayek, S. (2004). FDI and economic growth: the role of local financial markets. Journal of international economics, 64(1), 89-112.

Apter, D. E. (1987). Rethinking development: modernization, dependency, and postmodern politics (No. 330.9 A6). Beverly Hills, CA: Sage.

Aseidu, E. (2002). On the Determinants of Foreign Direct Investment to Developing Countries: is Africa Different? World Development, 30(1), 107-119.

Blomstrom, M., \& Kokko, A. (1996). Multinational corporations and spillovers. Journal of Economic Surveys, 12(2), 1-31.

Borensztein, E., De Gregorio, J., \& Lee, J. (1998). How does foreign direct investment affect economic growth? Journal of International Economics, 45 (1), 115-135.

Bwalya , S. M. (2006). Foreign direct investment and technology spillovers: Evidence from panel data analysis of manufacturing firms in Zambia. Journal of Development Economics, 81, 514-526.

Carkovic, M., \& Levine, R. (2005). Does foreign direct investment accelerate economic growth?. Does foreign direct investment promote development, 195.

Chakraborty, C., \& Nunnenkamp, P. (2008). Economic reforms, FDI and economic growth in India: a sector level analysis. World Development, 36(7), 1192-1212.

Dunning, J. (1992). Multinational Enterprises and Global Economy.

Dutse, A. Y. (2012). Technological Capabilities and FDI-related Spillover: Evidence from Manufacturing Industries in Nigeria. American International Journal of Contemporary Research, 2(8), 201-211.

Fourie, E. (2012). A future for the theory of multiple modernities: Insights from the new modernization theory. Social Science Information, 51(1), 52-69.

Ghali, s., \& Rezgui, S. (2008). FDI contribution to Technical Efficiency in the Tunisian Manufacturing Sector. Retrieved from http://papers.ssrn.com/sol3/papers.cfm?abstract_id=1260755 on 3/5/2011

IMF. (1991). A study of the Soviet economy. World Bank, OECD and EBRD. Paris: OECD.

Jordaan, J. (2008). Intra \& inter industry externalities from foreign direct investment in the Mexican manufacturing sector: new evidence from Mexican regions. World Development, 36(12), 2838-2854.

Kombui, D. N. \& Kotey, R. A. (2019). Foreign Direct Investment in an Emerging Economy: Exploring the Determinants and Causal Linkages. Academic Journal of Economic Studies, 5(1), 51-62.

Kotey, R. (2019). Foreign Direct Investment and Spillover Effects in Africa: An Empirical Review. International Journal of Science and Management Studies (IJSMS).

Larrain, J. (2013). Theories of development: Capitalism, colonialism and dependency. John Wiley \& Sons.

Lehmann, D. (2010). Development theory: four critical studies. Routledge. 
Li, X., \& Liu, X. (2005). Foreign direct investment and economic growth: an increasingly endogenous relationship. World Development, 33(3), 393-407.

Liu, Z. (2008). Foreign direct investment and technology spillovers: Theory and evidence. Journal of Development Economics 85 (2008), 176-193.

Marin, A., \& Bell, M. (2006). Technology Spillovers from Foreign Direct Investment (FDI): an Exploration of the Active Role of MNC Subsidiaries in the Case of Argentina in the 1990s. Journal of Development Studies, 42(4), 678-697.

Matunhu, J. (2011). A critique of modernization and dependency theories in Africa: Critical assessment.

Preston, P. (2012). Theories of development. Routledge.

Ramirez, M. (2006). Is foreign direct investment beneficial for Mexico? An empirical analysis, 1960-2001. World Development, 34(5), 802-817.

Rehman, N. U. (2016). FDI and economic growth: empirical evidence from Pakistan. Journal of Economic and Administrative Sciences, 32(1), 63-76. DOI:10.1108/JEAS-12-2014-0035

Scott, C. V. (1995). Gender and development: rethinking modernization and dependency theory. Lynne Rienner Publishers Inc.

Sinani, E., \& Meyer, K. E. (2004). Spillovers of technology transfer from FDI: the case of Estonia. Journal of Comparative Economics(32), 445-466.

So, A. Y. (1990). Social change and development: Modernization, dependency and world-system theories (No. 178). Sage.

Sylwester, K. (2005). Foreign direct investment, growth and income inequality in less developed countries. International Review of Applied Economics, 19(3), 289-300. DOI:10.1080/02692170500119748

Twarowska, K., \& Kakol, M. (2013). International business strategy- reasons and forms of expansion into foreign markets. Active citizenship by knowledge management and innovation. Zader Croatia.

UNCTAD. (1992). World Investment Report. United Nations, New York.

UNCTAD. (2005). Economic development in Africa; Rethinking the Role of Foreign Direct Investment (Vol. Sales No. E.05.II.D.12 I). New York and Geneva: United Nations Publications. DOI:UNCTAD//GDS/ AFRICA/2005/1

UNCTAD. (2010). Foreign direct investment, the transfer and diffusion of technology, and sustainable development. United Nations Conference on Trade and Development, (p. TD/B/C.II/EM.2/2). Geneva. 


\section{APPENDIX}

\section{Appendix 1}

The table below shows a list of variables used to measure technology in literature;

Frequently Used Measures for Technology found in Literature

\begin{tabular}{|c|c|c|c|}
\hline PROXY & STUDY & MERIT & DEMERIT \\
\hline $\begin{array}{c}\text { New products/product in- } \\
\text { novations }\end{array}$ & $\begin{array}{l}\text { Elenkov \& Manev (2009), } \\
\text { Sasidharan, (2006), Hale } \\
\text { and Long (2006) }\end{array}$ & $\begin{array}{l}\text { Measures actual imple- } \\
\text { mentation }\end{array}$ & Not all products succeed \\
\hline $\begin{array}{r}\text { Patents/patent applica- } \\
\text { tions }\end{array}$ & $\begin{array}{l}\text { Makri \& Scandura (2010), } \\
\text { Jung et al. (2008), }\end{array}$ & $\begin{array}{l}\text { Measures technological } \\
\text { progress and the impor- } \\
\text { tance of patents }\end{array}$ & $\begin{array}{c}\text { In some situations, Patents } \\
\text { are not useful. patenting } \\
\text { is not harmonized across } \\
\text { countries }\end{array}$ \\
\hline Invention disclosures & Axtell et al. (2000) & $\begin{array}{l}\text { Measures technological } \\
\text { progress and the number } \\
\text { of ideas generated }\end{array}$ & $\begin{array}{l}\text { Ideas might not become } \\
\text { products }\end{array}$ \\
\hline Innovations in pro & $\begin{array}{l}\text { Marin and Bell (2006; } \\
\text { 2008), West et al. (2003), } \\
\text { Kinoshita (2000) }\end{array}$ & $\begin{array}{l}\text { Measures improvements } \\
\text { in processes and methods }\end{array}$ & $\begin{array}{l}\text { Difficult to measure, the } \\
\text { challenge of innovators } \\
\text { dilemma. }\end{array}$ \\
\hline $\begin{array}{l}\text { Ratio of new product sales } \\
\text { to total sales }\end{array}$ & $\begin{array}{c}\text { Bwalya (2006), Czarnitzki } \\
\text { \& Kraft (2004), Javorcik \& } \\
\text { Spatareanu (2008) }\end{array}$ & $\begin{array}{l}\text { Measures customers re- } \\
\text { sponse to innovation }\end{array}$ & $\begin{array}{c}\text { Sales output is affected by } \\
\text { many variables }\end{array}$ \\
\hline $\begin{array}{r}\text { Ratio of ner } \\
\text { to cos }\end{array}$ & $\begin{array}{l}\text { Gumusluoglu \& Ilsev } \\
\text { (2009), UNCTAD (2010) }\end{array}$ & $\begin{array}{l}\text { Show how } \mathrm{R} \& \mathrm{D} \\
\text { pacted sales }(\mathrm{ef}\end{array}$ & $\begin{array}{r}\text { Sales outpu } \\
\text { many }\end{array}$ \\
\hline Cost of R\&D & $\begin{array}{l}\text { UNCTAD (2010), García- } \\
\text { Morales et al. (2008), Ne- } \\
\text { ven \& Siotis (1996), Lan- } \\
\text { cheros (2016) }\end{array}$ & $\begin{array}{l}\text { Data very available (Most } \\
\text { used measure of technol- } \\
\text { ogy) }\end{array}$ & $\begin{array}{l}\text { Does not measure the ef- } \\
\text { ficiency }\end{array}$ \\
\hline $\begin{array}{l}\text { Number of employees into } \\
\text { R\&D }\end{array}$ & $\begin{array}{l}\text { UNCTAD (2010), García- } \\
\text { Morales et al. (2008) }\end{array}$ & $\begin{array}{l}\text { Data very available (Most } \\
\text { used measure of technol- } \\
\text { ogy) }\end{array}$ & $\begin{array}{l}\text { Does not measure the ef- } \\
\text { ficiency }\end{array}$ \\
\hline Entry into New markets & Elenkov \& Manev (2009) & $\begin{array}{l}\text { Measures innovation and } \\
\text { efficiency }\end{array}$ & Some acquisitions fail \\
\hline Productivity and efficiency & $\begin{array}{l}\text { Liu (2008), Dutse (2012), } \\
\text { Chuang and Lin (1999), }\end{array}$ & $\begin{array}{l}\text { Easy to measure/ Quan- } \\
\text { tifiable }\end{array}$ & $\begin{array}{c}\text { Productivity is the result } \\
\text { of many variables }\end{array}$ \\
\hline $\begin{array}{l}\text { Knowledge creation and } \\
\text { skills (labour) }\end{array}$ & $\begin{array}{l}\text { UNCTAD (1999), Gorg } \\
\text { and Greenaway (2001), } \\
\text { Pradhan (2006), Seghir, } \\
\text { (2012), Bwalya (2006) }\end{array}$ & $\begin{array}{l}\text { Relatively closer measure } \\
\text { of technology }\end{array}$ & $\begin{array}{c}\text { May be affected by more } \\
\text { than one variable and hard } \\
\text { to disentangle. }\end{array}$ \\
\hline $\begin{array}{c}\text { Payments of Royalties and } \\
\text { License fees }\end{array}$ & UNCTAD (2010) & $\begin{array}{l}\text { Quantifiable and easy to } \\
\text { compute }\end{array}$ & $\begin{array}{l}\text { May be a weak form of } \\
\text { measure in some cases. }\end{array}$ \\
\hline
\end{tabular}




\section{Appendix 2}

The table below presents a view of SSA countries and their annual publications.

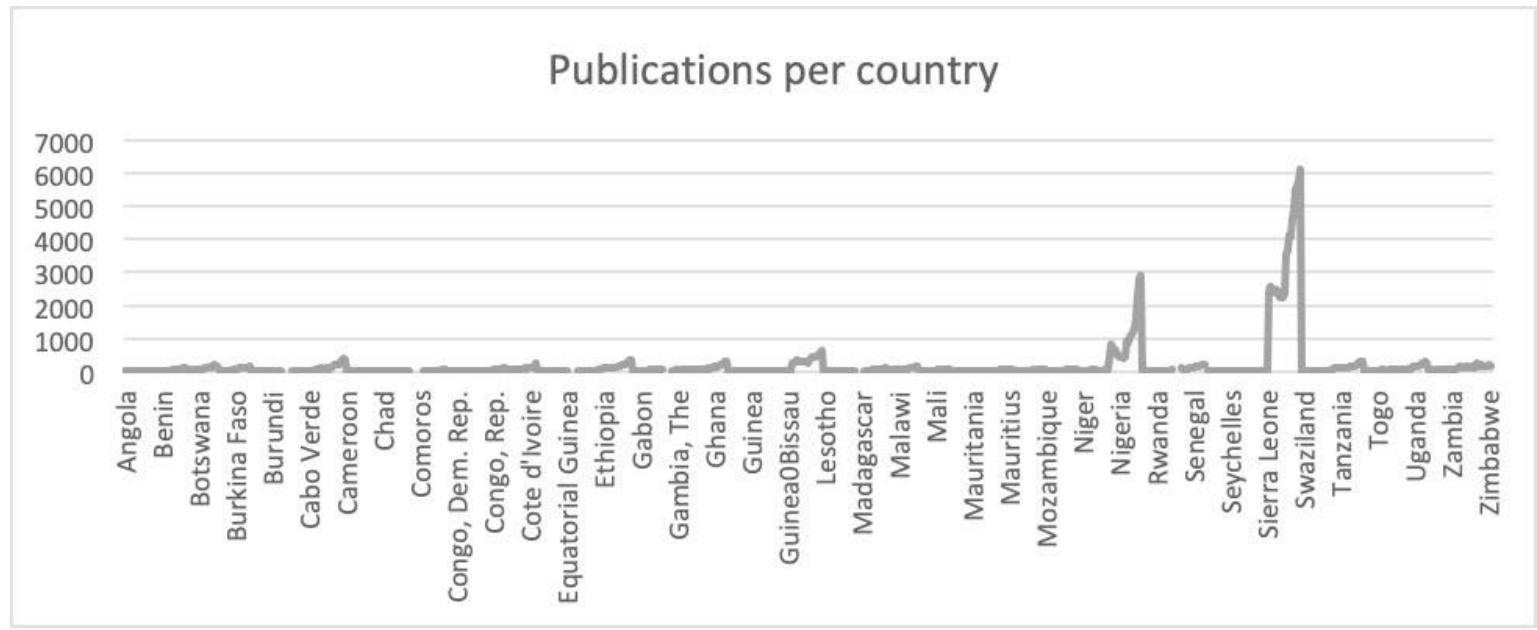

\section{Appendix 3 Pre-Estimation Tests}

\section{Breusch-Pagan / Cook-Weisberg test for heteroskedasticity}

The table below presents our test results after we perform the Breusch-Pagan / Cook-Weisberg test for heteroskedasticity.

Test for Heteroscedasticity

Breusch-Pagan / Cook-Weisberg test for heteroskedasticity

Ho: Constant variance

Variables: fitted values of GDP

\begin{tabular}{lll}
\hline chi $2(1)$ & $=$ & 0.08 \\
\hline Prob $>$ chi2 & $=$ & 0.7743
\end{tabular}

Our P-value (of 0.7743), from the test is insignificant, indicating that the variation from the regression line is constant among our data points and therefore, the normal standard errors are not biased. Also, we observe from our scatter plot that there is no heteroscedasticity; data that exhibits heteroscedasticity are usually cone-shaped. 


\section{HAUSMAN TEST}

The table below presents the Hausman test results;

Hausman test results

\begin{tabular}{|c|c|c|c|c|}
\hline & \multicolumn{4}{|c|}{--- Coefficients ---- } \\
\hline & (b) & (B) & $(b-B)$ & $\operatorname{sqrt}\left(\operatorname{diag}\left(\mathrm{V} \_b-\mathrm{V} \_\mathrm{B}\right)\right)$ \\
\hline & $\mathrm{FE}$ & $\mathrm{RE}$ & Difference & S.E. \\
\hline FDI & -0.0841837 & -0.0754175 & -0.0087662 & 0.0047944 \\
\hline Tech & 0.0000305 & 0.0000275 & $2.97 \mathrm{E}-06$ & 3.17E-06 \\
\hline lninteraction & 0.1090934 & 0.1070176 & 0.0020758 & 0.004901 \\
\hline $\operatorname{lnExpcu}$ & 0.5883393 & 0.6519714 & -0.0636321 & 0.0115638 \\
\hline Open & -0.0972443 & -0.1144304 & 0.0171861 & 0.007321 \\
\hline Labper & -1.683713 & -1.251441 & -0.4322716 & 0.0618394 \\
\hline \multirow[t]{3}{*}{$\operatorname{chi2}(6)$} & $=$ & $(b-B)^{\prime}\left[\left(V \_b-V \_B\right)^{\wedge}(-1)\right](b-B)$ & & \\
\hline & & 37.66 & & \\
\hline & & Prob $>$ chi 2 & & \\
\hline
\end{tabular}

The chi-square for the test is 37.66 and the $\mathrm{P}$-value is 0.000 which is significant so we reject the null hypothesis and conclude FE model is appropriate for the regression. Thus, there is some correlation between the independent variable and error term hence random effects estimation is not appropriate for the model. 


\section{Test for endogeneity}

To test for possible endogeneity, simultaneity and reverse causality issues, we run an IV (instrumental variable) regression. We employed a Two-Stage Least Squares. The table below is the regression output.

Table 9 Test for Endogeneity using 2stage least squares

\begin{tabular}{lll}
\hline & $(1)$ & $(2)$ \\
\hline Variables & $\ln G D P$ & $\ln G D P$ \\
\hline $\operatorname{lnFDI}$ & -0.136 & -0.104 \\
\hline lninteraction & $(0.0975)$ & $(0.0790)$ \\
\hline & $0.176^{* * *}$ & $0.193^{* * *}$ \\
\hline lnExpcu & $(0.0614)$ & $(0.0707)$ \\
\hline & $0.659^{* * *}$ & $0.598^{* * *}$ \\
\hline Open & $(0.0378)$ & $(0.0687)$ \\
\hline & -0.000104 & -0.000279 \\
\hline Labper & $(0.000423)$ & $(0.000336)$ \\
\hline Pstab & $-0.750^{* * *}$ & $-0.626^{* * *}$ \\
\hline & $(0.190)$ & $(0.167)$ \\
\hline Constant & $-0.0953^{* * *}$ & $-0.0922^{* * *}$ \\
\hline & $(0.0147)$ & $(0.0135)$ \\
\hline & $3.326^{* * *}$ & $3.459^{* * *}$ \\
\hline Observations & $(0.460)$ & $(0.531)$ \\
\hline R-squared & & 372 \\
\hline Stand & 372 & 0.918 \\
\hline
\end{tabular}

Standard errors in parentheses

*** $p<0.01, * * p<0.05, * p<0.1$

From the above table, we observe a very high R-squared (of about 92\%) for both models. When the coefficients for the interaction term and FDI are observed, we see the results are similar to the main FE regression model the study employed. Therefore, when we control of endogeneity, the regression results do not change that much. That means endogeneity may not be a problem in the main regression. 


\section{ULOGA TEHNOLOGIJE KAO APSORPCIONOG KAPACITETA U PRIVREDNOM NAPRETKU ZEMALJA U RAZVOJU: NOVI PRISTUP}

\section{Rezime:}

Istraživanja su pokazala da efekti direktnih stranih investicija na ekonomski rast nisu uvek bili neposredni, posebno ne u oblastima koje se razvijaju; potrebno je da u samoj privredi već postoje određene osobenosti, a kako bi se navedeni efekti pravilno absorbovali. Otuda, ovo istraživanje je imalo za cilj da proceni ekonomski uticaj direktnih stranih investicija na ekonomski rast zemalja Supsaharske Afrike, uzimajući u obzir tehnologiju kao apsorpcioni kapacitet. Zbog nedostatka podataka o održivom merilu, a kada je u pitanju tehnologija iz perspektive Afrike, promeravamo tehnologiju uz upotrebu inovativnog pristupa, koristeći godišnji broj objavljenih radova u vezi sa inovacijama, kao merilo tehnološkog prisustva. Analizirani su podaci iz četrdeset tri supsaharske zemlje, koji ilustruju period od 19 godina (od 1990. do 2008). Upotrebom regresionog modela fiksnih efekata (Fixed Effects), istraživanje je pokazalo da direktne strane investicije imaju negativan i značajan uticaj na bruto domaći proizvod (BDP), što je naš parametar za ekonomski razvoj. Ipak, kada se investicije udruže sa tehnologijom, ovaj odnos postaje značajan i pozitivan. Navedeno pokazuje da zemlje u kojima je tehnologija razvijenija lakše prihvataju i koriste strane direktne investicije, u odnosu na zemlje u kojima je tehnologija slabije razvijena.
Ključne reči:

direktne strane investicije, tehnologija, inovacije, apsorpcioni kapacitet 